\title{
Immunities of the European Union
}

\author{
Ramses A. Wessel \\ Professor of International and European Institutional Law, \\ University of Twente, The Netherlands \\ r.a.wessel@utwente.nl \\ Forthcoming in International Organizations Law Review, Volume 10, 2013, No. 2
}

\begin{abstract}
The question of the immunities of the European Union ('EU') is clearly under-researched. However, with the new global ambitions of the EU, which are even more prominent in the current — post-Lisbon Treaty - legal regime, the classic institutional law theme of the immunities of international organizations deserves to be addressed in the context of the EU as well. This contribution first of all looks into the legal position of the EU under international law. This is followed by an analysis of the legal provisions on the EU's immunities in the treaties and other relevant documents. The paper also addresses actual and potential situations in which EU immunities are or can be invoked. It is concluded that, although the EU's legal regime in this area follows the rules of international diplomatic law, it is special because of the extensive, yet complex, international competences of the EU as well as of the role of the organization's own Court of Justice.
\end{abstract}

\section{Keywords}

European Union; privileges and immunities; international organizations.

\section{Introduction}

The European Union ('EU' or 'Union') is usually perceived as being 'special' or perhaps even 'sui generis'. These qualifications not only relate to the Union's relationship with its own members and the effects of its decisions in their domestic legal orders, but also to the relations it maintains with non-Member States ('third states' in EU jargon). Originally, these external relations of the Union related primarily to 'trade and aid' issues; but over the past fifteen years or so, the EU has become more active in other policy fields as well, which is also due to a coming of age of its foreign, security and defence policy and the development of the external dimension of some of its internal policy fields (such as the environment or criminal and judicial cooperation). The 'EU as a global actor' has become a widely studied theme, by lawyers and political scientists alike. ${ }^{1}$

Whereas some dimensions of the Union's global activities (such as the international responsibilities of the EU, the relationship between EU law and international law, or the division of external competences between the EU and its Member States) have gradually become subject

1 See for a recent example B. Van Vooren, S. Blockmans and J. Wouters (eds.), The EU's Role in Global 
to frequent academic research, ${ }^{2}$ the same does not hold true for the topic of the present contribution. Although the 'privileges and immunities' form a classic theme in the law of international organizations, ${ }^{3}$ studies on the immunities of the EU are very hard to find, ${ }^{4}$ and colleagues at the legal services of the EU Institutions are even somewhat surprised when asked about the issue.

However, with the new global ambitions of the EU, ${ }^{5}$ which are even more prominent in the current - post-Lisbon Treaty - legal regime, the classic institutional law theme of the immunities deserves to be addressed in the context of the EU as well. While limited in scope and far from exhaustive, this contribution seeks to do exactly that. Section I first of all looks into the legal position of the European Union under international law. This is followed by an analysis of the - limited - legal provisions on the EU's immunities in the treaties and other relevant documents (in Section II). Section III deals with actual and potential situations in which EU immunities are or can be invoked; and finally some general conclusions will be drawn.

\section{The Position of the European Union in International Law}

The question of the immunities of the EU is first of all linked to the relationship between the organization and its Member States. With respect to the EU, this relationship is usually perceived as being different from any other international organization. The reason is that Member States have been willing to attribute extensive competences to the EU, which allows most of its decisions to be 'directly effective' in the domestic legal orders (allowing citizens and companies to invoke EU law before national courts) and to allot 'primacy' to EU law in case of a conflict

2 To mention just a few recent examples: M. Evans and P. Koutrakos (eds.), The International Responsibility of the European Union - European and International Perspectives (Oxford University Press, Oxford, 2013); E. Cannizzaro, P. Palchetti and R. A. Wessel (eds.), International Law as Law of the European Union (Martinus Nijhoff Publishers, Boston/Leiden, 2011); P. Eeckhout, EU External Relations Law (Oxford University Press, Oxford, 2011 ( $^{\text {nd }}$ ed.).

3 Given the specific focus of the present contribution, we will not analyse the issue of the immunities of international organizations in general. See for instance P. H. Bekker, The Legal Position of International Governmental Organizations - A Functional Necessity Analysis of their Legal Status and Immunities (Martinus Nijhoff Publishers, Dordrecht, 1994); A. Reinisch, International Organizations before National Courts (Cambridge University Press, Cambridge, 2000); as well as some other contributions to this special issue.

4 With some exceptions in the francophone academic community, including M. Benlolo-Carabot, 'Les immunités de l'Union Européenne dans les États tiers' (2009) Annuaire Français de Droit International, pp. 783-818; and S. Barbier and M. Cuq, 'Les immunités de l'Union Européenne', in M. Benlolo-Carabot, U. Candas and E. Cujo (eds.), Union Européeenne et Droit International (Editions Pedone, Paris, 2012) pp. 407-427.

5 Cf. R. A. Wessel and B. Van Vooren, 'The EEAS' Diplomatic Dreams and the Reality of International and European Law' (2013) Journal of European Public Policy pp. 1350-1367. 
with national rules. ${ }^{6}$ The complex relationship between the EU and its Member States has resulted in debates on the nature of the EU and in particular on the question of whether it would not come closer to being a federation than to an international organization. ${ }^{7}$ Yet, it seems fair to say that as long as the Member States did not cease to exist as independent states, there is a clear distinction between them and the organization of which they are a member. ${ }^{8}$ Indeed, as will be shown below, this distinction has consequences for the legal status of the EU in its Member States, and hence for those Member States "to respect the autonomy of the organization through, inter alia, the recognition of [its] legal personality and [its] privileges and immunities". 9 At the same time, there are consequences for the legal status of (representatives) of Member States when acting in the (institutional) framework of the EU.

As far as the legal position of the Union in its own Member States is concerned, Article 335 of the Treaty on the Functioning of the European Union ('TFEU') provides the following:

\begin{abstract}
"In each of the Member States, the Union shall enjoy the most extensive legal capacity accorded to legal persons under their laws; it may, in particular, acquire or dispose of movable and immovable property and may be a party to legal proceedings. To this end, the Union shall be represented by the Commission. However, the Union shall be represented by each of the institutions, by virtue of their administrative autonomy, in matters relating to their respective operation."
\end{abstract}

This internal distinction has an external counterpart. The (separate) legal personality of an international organization not only distinguishes it from its Member States, but also turns it into an autonomous international actor within the limits set by the international capacities attributed to it. Through the succession of the European Community by the European Union on the basis of the Lisbon Treaty (Article 1 of the Treaty on European Union, or the 'TEU'), the world was confronted with an international legal actor with new competences. Prior to the Lisbon Treaty, the EU did of course exist on the global stage: not only politically, but also legally given the large number of international agreements to which it became a party. ${ }^{10}$ However, for many the explicit recognition of the European Union's legal personality (Article 47 of the TEU) — or perhaps even

6 See for instance B. de Witte, 'Direct Effect, Primacy, and the Nature of the Legal Order', in P. Craig and G. De Búrca (Eds.), The Evolution of EU Law (Oxford University Press, Oxford, 2012 (2 ${ }^{\text {nd }}$ ed.) pp. 323-362.

$7 \quad C f$. the contributions to 'L'Union Européenne Comme Fédération', Chapter 2 in Benlolo-Carabot et al., supra note 4, pp. 139-230.

8 See more extensively on this distinction R. A. Wessel, 'Revisiting the International Legal Status of the EU' (2000) European Foreign Affairs Review pp. 507-537.

9 D. M. Curtin and I. F. Dekker, 'The European Union from Maastricht to Lisbon: Institutional and Legal Unity out of the Shadow', in P. Craig and G. De Búrca (eds.), The Evolution of EU Law (Oxford University Press, Oxford, 2011) pp. 155-185, at p. 161.

10 R. A. Wessel, 'The European Union as a Party to International Agreements: Shared Competences, Mixed Responsibilities', in A. Dashwood and M. Maresceau (eds.), Law and Practice of EU External Relations Salient Features of a Changing Landscape (Cambridge University Press, Cambridge, 2008) pp. 145-180. 
more the dissolution of the European Community ${ }^{11}$ — provided a reason to reassess the Union's international role and to take a different perspective in relation to its international legal status. ${ }^{12}$

To be able to assess the issue of the EU's immunities under international law, it is necessary to classify the European Union as an international actor. ${ }^{13}$ The Lisbon Treaty strengthens the international role of the Union in an unprecedented number of provisions. Most international rules apply to states, some (also) to international organisations and a limited set also to other internationally active entities (such as liberation movements or multinationals). Few would argue that the EU is a state; ${ }^{14}$ many would say that it is an international entity sui generis. International law, however, only works when it is applied across the board for certain categories of international actors. While it may be possible to create special rules for sui generis entities (compare the clauses on Regional Economic Integration Organisations ('REIOs') in some multilateral agreements $)^{15}$, the rationale behind a legal system is that its rules should allow for a smooth cooperation between the different subjects.

11 See the last sentence of Art. 1 of the TEU: "The Union shall replace and succeed the European Community". The European Atomic Energy Community ('Euratom') still exists as a separate international legal entity.

12 See for a recent contribution to the classic debate on the Union's legal status: W. Schroeder, 'Die Europäische Union als Völkerrechtssubject' (2012) Europarecht, Beiheft 2, pp. 9-23. Schroeder also refers to a purpose of the explicit recognition of the Union's legal personality: it provides legal certainty in international relations (p. 17). See earlier: R.A. Wessel, 'The International Legal Status of the European Union' (1997) European Foreign Affairs Review pp. 109-129; and 'Revisiting the International Legal Status of the EU' (2000) European Foreign Affairs Review pp. 507-537.

13 Van Vooren, Blockmans and Wouters, supra note 1. This section is partly based on R.A. Wessel, 'Can the EU Replace its Member States in International Affairs? An International Law Perspective' [forthcoming]; and B. van Vooren and R.A. Wessel, EU External Relations Law: Text, Cases and Materials (Cambridge University Press, Cambridge, 2014, forthcoming) Chapter 1.

14 Although it can be argued that there are close resemblances with federations such as Canada.

15 A REIO is commonly defined in UN protocols and conventions as

"an organization constituted by sovereign states of a given region to which its Member States have transferred competence in respect of matters governed by ... convention or its protocols and [which] has been duly authorized, in accordance with its internal procedures, to sign, ratify, accept, approve or accede to it [the instruments concerned]."

See for example the 2004 Energy Charter Treaty (Art. 3). See also E. Paasivirta and P.J. Kuijper, 'Does one size fit all?: The European Community and the Responsibility of International Organisations' (2007) Netherlands Yearbook of International Law (T.M.C. Asser Press, The Hague), pp. 169-226, at p. 205. In the new Convention on the Rights of Persons with Disabilities the REIO clause seems to have evolved to a RIO (Regional Integration Organisation) clause, which does justice to the large scope of activities of the EU these days (see Art. 44: “'Regional integration organisation' shall mean an organisation constituted by sovereign States of a given region, to which its member States have transferred competence in respect of matters governed by this Convention.") 
The EU Treaties themselves are still silent on this issue. Article 1 of the TEU merely refers to the fact that "the High Contracting Parties establish among themselves a European Union" and that this Union "shall replace and succeed the European Community". Thus, it still does not give an answer to the classic question of whether the EU is an international organization or something else. Throughout their handbook on the law of international organizations, Schermers and Blokker nevertheless take the EU along as an international organization, while noting of course its "far-reaching forms of cooperation" and the "supranational features". ${ }^{16}$ The EU is indeed "considered special not because of its identity problems but because of the high degree of 'constitutional' development, supranational components and the rule of law features within this organization making it look almost like a federation of states", as argued by Bengoetxea in one of the few publications focussing on this question. ${ }^{17}$

As an international organization, the $\mathrm{EU}$ is subject to international law in its relations with third states and other international organizations. Yet, third states experience that the EU remains special. It may be an international organization, but the fact that it is exclusively competent to act in certain areas is unprecedented, as is the rule that EU Member States feel that, in the end, they should give priority to EU law in cases of a conflict with international law. ${ }^{18}$ Indeed, as also more recent case law underlines, the Gemeinschaftstreue is believed to take precedence over international law obligations. While for EU Member States (and most EU lawyers) these may be logical consequences of a dynamic division of competences, third states (and most public international lawyers) would remind us of the rule of pacta tertiis nec nocent nec prosunt; third states are in principal not bound by the EU Treaty as to them it is an agreement between others. ${ }^{19}$ From a legal perspective they should not be bored with a complex division of competences that was part of a deal between the EU and its own Member States. And, as they would rightfully

16 H. G. Schermers and N. M. Blokker, International Institutional Law: Unity in Diversity (Martinus Nijhoff Publishers, Leiden/Boston, 2011) p. 55 and p. 57. See also R. A. Wessel, The European Union: An International Perspective, in T. Tridimas and R. Schütze (Eds.), The Oxford Principles of European Union Law - Volume 1: The European Union Legal Order (Oxford University Press, Oxford, 2014, forthcoming).

17 J. Bengoetxea, 'The EU as (More Than) an International Organization', in J. Klabbers and A. Wallendahl, Research Handbook on the Law of International Organizations (Edward Elgar Publishing, Cheltenham/Northhampton, 2011) pp. 448-465, at p. 449. The author argues that it is above all the 'transitional' status of the EU (from international organization to federation) that justifies its 'specialness' (at p. 450). See also the contributions to the Chapter on: 'L'Union Européenne comme organisation international?' in BenloloCarabot, et al., supra note 4, pp. 96-138.

18 See more generally J. Klabbers, Treaty Conflict and the European Union (Cambridge University Press, Cambridge, 2009).

19 This rule is laid down in Article 34 of the 1969 Vienna Convention on the Law of Treaties, opened for signature 23 May 1969, 1155 UNTS p. 331 (entered into force 27 January 1980) ('VLCT'): “A treaty does not create either obligations or rights for a third State without its consent". 
argue, other rules of international law (pacta sunt servanda, and the provision laid down in Article 27 of the VCLT not to invoke the provisions of internal law as a justification for a failure to perform) may stand in the way of the use of internal EU arguments.

Obviously, these characteristics are relevant for the possible immunities the EU may enjoy under international law or under the law of non-Member States. The increasing international activities of the EU abroad (e.g. through over 20 military and civilian missions on three different continents ${ }^{20}$ and 139 'Union Delegations' as 'EU Embassies' around the world ${ }^{21}$ ) may lead to an increase in legal conflicts. It is good to keep in mind, however, that irrespective of the fact that the Union's international ambitions become more apparent, it lacks the competences that traditionally come with statehood. Many of the key dimensions of international diplomacy such as the recognition of states or the acknowledgment of reciprocity in relation to privileges and immunities - cannot be exercised by the EU. Article 2 of the 1961 Vienna Convention on Diplomatic Relations, for instance, provides that states agree by mutual consent to establish "diplomatic relations between states". ${ }^{22}$ This leaves the Union to turn to ad hoc solutions, for instance by contracting in to the international rules on diplomatic or consular cooperation and protection, to convince third states to accept a laissez-passer document as a diplomatic passport or to task one of its Member States, Belgium, "to accord the customary diplomatic immunities and privileges to missions of third countries accredited to the Union"23

\section{The Regulation of EU Immunities}

\section{A. Primary Law Provisions}

The situation that the Union is a party to a dispute taking place within one of its Member States is foreseen by the treaty, and in fact a role of the national courts is not excluded. This absence of full jurisdictional immunity results in a special situation, which is highly exceptional for international organizations. Article 274 of TFEU provides:

"Save where jurisdiction is conferred on the Court of Justice of the European Union by the Treaties, disputes to which the Union is a party shall not on that ground be excluded from the jurisdiction of the courts or tribunals of the Member States."

Yet, the provision in Article 274 should be seen in the context of other rules and principles in EU law. Given the extensive (and often exclusive) jurisdiction of the Court of Justice of the European Union ('CJEU' or 'Court of Justice') (see below), the jurisdiction of the domestic courts in these

20 P. Koutrakos, The EU Common Security and Defence Policy (Oxford University Press, Oxford, 2013).

21 Cf. Wessel \& Van Vooren, supra note 5.

22 Opened for signature on 18 April 1961, 500 UNTS p. 95 (entered into force 24 April 1964).

23 Article 16 of the Protocol. The Protocol is attached to the EU Treaties as 'Protocol No.7 on the Privileges and Immunities of the European Union'. 
cases will be residual at best. ${ }^{24}$ At the same time, Article 343 of the TFEU provides for the regulation of privileges and immunities in the Member States:

"The Union shall enjoy in the territories of the Member States such privileges and immunities as are necessary for the performance of its tasks, under the conditions laid down in the Protocol of 8 April 1965 on the privileges and immunities of the European Union. The same shall apply to the European Central Bank and the European Investment Bank."

A similar provision can be found in Article 191 of the Treaty establishing the European Atomic Energy Community ('EAEC' or 'Euratom'), an international organization that is part of the EU family and shares its institutions. The Protocol referred to regulates the immunities and privileges in more detail and forms the backbone of the EU's legal regime in this area. ${ }^{25}$ Chapter 1 deals with the inviolability of the premises and buildings of the Union. Article 1 provides that the property and assets of the Union shall not be the subject of any administrative or legal measure of constraint without the authorisation of the Court of Justice and Article 2 provides that the archives of the Union shall be inviolable. This provision thus reflects the Union's immunity from execution in quite absolute terms. ${ }^{26}$ The question of whether and when the 'property and assets' are really at stake may nevertheless be difficult to answer. In a case in the UK it became clear that, in the eyes of the Commission, the 'property and assets of the Union' "can include some else's property or assets if a measure of constraint upon it would interfere with the functioning of the Commission". The Court, in any case, held that funds held by Sierra Leone, although partly granted by the Commission in the framework of an agricultural aid programme in the framework of the Lomé Convention, could not be considered as property of the European Community in the sense of the Protocol. ${ }^{27}$

Furthermore, provisions have been included in the Protocol to regulate the exemption from all direct taxes and the governments of the Member States shall, wherever possible, take the appropriate measures to remit or refund the amount of indirect taxes or sales taxes. In addition, the Union shall be exempt from all customs duties, prohibitions and restrictions on imports and exports in respect of articles intended for its official use. Chapter 2 contains the communications and laissez-passer rules and provides for a treatment accorded by states to diplomatic missions for the official communications and the transmission of all documents. It also regulates the socalled laissez-passer documents, which may be issued to EU officials and are to be recognised as valid travel documents by the authorities of the Member States. The Commission may conclude agreements for these documents to be recognised as valid travel documents within the territory of

24 See also Barbier and Cuq, supra note 4, at p. 413.

25 Protocol No.7 on the Privileges and Immunities of the European Union ('Protocol').

26 Cf. Benlolo-Carabot, supra note 4, at p. 810.

27 Ibid. at p. 811. See Court of Appeal, 24 November 1994, Philipp Brothers v. Sierra Leone and Commission of the European Communities, 107 ILR pp. 517-535. 
third countries, and usually a specific provision to this effect forms part of the agreement establishing an EU Delegation in a non-EU country (see below).

Chapter 3 deals with special privileges and immunities for members of European Parliament (see also below). The privileges, immunities and facilities of Representatives of Member States taking part in the work of the institutions of the Union (including their advisers and technical experts) are the subject of Chapter 4 of the Protocol. Furthermore, Chapter 5 lists an extensive number of privileges for officials and other servants of the Union in the territories of the Member States. It includes the right to be immune from legal proceedings in respect of acts performed by them in their official capacity; the right not be subject to immigration restrictions or to formalities for the registration of aliens; the right to be accorded the same facilities as are customarily accorded to officials of international organizations; the right to import and export their furniture free of duty; and the right to import free of duty a motor car for their personal use. In addition, officials and other servants of the Union shall be liable to a tax for the benefit of the Union on salaries, wages and emoluments paid to them by the Union and they shall be exempt from national taxes on salaries, wages and emoluments paid by the Union. Finally, Chapter 6 regulates the position of missions of third countries accredited to the Union: they have to be accorded the customary diplomatic immunities and privileges.

In addition to the rules on privileges and immunities, the EU Treaty contains quite extensive rules on contractual and non-contractual claims. Irrespective of the general rules on immunities described above, the Union thus a priori accepts that it can be confronted with claims. On the basis of Article 340 of the TFEU, the contractual liability of the Union shall be governed by the law applicable to the contract in question. The underlying contract will normally determine the applicable dispute settlement procedure. It is important to distinguish between cases in which the implementation of EU external aid projects or programmes is executed on a centralised basis, with the European Commission acting as contracting authority, and cases in which it is executed on a decentralised basis, with the administration of the beneficiary third state acting as contracting authority. The clauses of the external aid contracts in which the European Commission is the contracting authority either designate a court in the EU (usually the Belgian courts in Brussels) as the competent court for any contractual dispute or provide for arbitration. The contract, as a rule, encourages the parties to the contract to seek to resolve the dispute amicably. $^{28}$

In relation to non-contractual claims, Article 340 of the TFEU furthermore provides that the Union shall, in accordance with the general principles common to the laws of the Member States, make good any damage caused by its institutions or by its servants in the performance of their duties. The personal liability of its servants towards the Union is governed by the provisions laid down in their Staff Regulations or in the Conditions of Employment applicable to them. On the basis of Article 268 of the TFEU, the Court of Justice has exclusive jurisdiction in disputes relating to compensation for damages in the case of non-contractual liability. Furthermore,

28 See the informal note issued by the European Commission in March 2010 (available online at $<$ www.coe.int/t/dlapil/cahdi/Source/state_immunities/EU\%20Immunities.pdf>. 
Article 46 of the Statute of the Court of Justice provides that proceedings in matters arising from non-contractual liability shall be barred after a period of five years from the occurrence of the event giving rise thereto.

The special situation of Member States' staff seconded to the EU bodies and acting on their behalf within EU Member States is regulated by the 2003 EU Status of Forces Agreement ('SOFA') on deployment in other EU Member States. ${ }^{29}$ Whereas SOFAs usually deal with the position of EU staff in non-EU countries (see below), the purpose of this very agreement is to define the legal position of the military and civilian personnel, as well as the forces and headquarters, deployed by one EU Member State in the territory of another Member State in the context of the EU's Common Security and Defence Policy ('CSDP'). The EU SOFA grants certain immunities to military and civilian staff seconded to the institutions of the EU and provides for the mandatory waiver of these immunities in certain circumstances. ${ }^{30}$

The extensive rules on claims and in particular on the (exclusive) role of the Court of Justice in dealing with those claims underlines the special nature of the European Union in this respect. Whereas most international organizations lack a judicial forum in which individuals may bring claims, the EU's well-developed legal order allows any natural or legal person whatever his nationality or residence to institute proceedings against a decision addressed to him or which is of direct and individual concern. On the basis of Articles 263 and 265 of the TFEU, the Court of Justice can decide on the legality of acts of the European institutions that produce legal effects (or can establish a failure to act). Whereas the Court of Justice thus serves as a judicial forum for both EU Member States and their citizens and legal persons, its jurisdiction is limited by the Treaties. With respect to the Union's external relations, the most important exception concerns (most) acts adopted under the Union's common foreign and security policy ('CFSP') and CSDP (Articles 24(1) of the TEU and 275 of the TFEU). ${ }^{31}$ Since the entry into force of the Lisbon Treaty, however, the Court of Justice is competent to rule on proceedings, brought in accordance with the conditions laid down in the fourth paragraph of Article 263 of the TFEU, reviewing the legality of decisions providing for restrictive measures against natural or legal persons. This is the result of the proliferation of sanctions targeted at individuals in the (global) fight against terrorism. The implication is that, even if the restrictive measures are only laid down in CFSP measures, ${ }^{32}$ the Court has jurisdiction once the plaintiff is directly and individually concerned.

29 Concluded by the Representatives of the Governments of the Member States meeting within the Council in 2003, OJ C 321/6, 2003.

30 See more extensively A. Sari, 'The European Union Status of Forces Agreement (EU SOFA)' (2009) 14 Journal of Conflict and Security Law pp. 353-391.

$31 C f$. M. Brkan, 'Then Role of the European Court of Justice in the Field of Common Foreign and Security Policy after the Treaty of Lisbon: New Challenges for the Future', in P. J. Cardwell (ed.), EU External Relations Law and Policy in the Post-Lisbon Era (T.M.C. Asser Press, The Hague, 2011) pp. 97-115.

32 It goes without saying that the Court has jurisdiction in relation to restrictive measures not based on a CFSP Decision, but on a Council Regulation following the procedure in Art. 215 of the TFEU, even if there is a relation 
Obviously, the limitations in the area of foreign and security policy seriously limit the role the Court can play in dealing with claims once these relate to this policy area.

\section{B. $\quad$ Agreements with non-EU countries}

Apart from the provisions in the EU Treaties and the Protocol, more specific regulation of the EU's immunities is laid down in the agreements concluded between the EU and third states or other international organizations. Here we will focus on the two most important types of agreements: agreements on the establishment of an EU Delegation in a third state or at an international organization; and status of forces/mission agreements (SOFAs and SOMAs) in the area of the Union's security and defence policy.

The recent establishment of the European External Action Service ('EEAS'), ${ }^{33}$ with its extensive diplomatic network of (currently) 139 'Union Delegations' throughout the world, obviously raises new questions in relation to the ways in which the Delegations can become a party to domestic disputes abroad and the possibilities for invoking the immunity of the Union in these disputes. The former type of delegations (which were in fact missions of the European Commission) already enjoyed extensive privileges and immunities which often went beyond the general rules in the 1961 Vienna Convention on Diplomatic Relations, ${ }^{34}$ and many of these agreements function as (the basis for) the current arrangements between the EU and third states. The broad scope of privileges and immunities granted to the EU is often accepted by its international partners. The United States, for instance, used two arguments to justify the extensive scope: first, the need for reciprocity in relation to the legal regime the US delegation at the EU enjoyed; and second, the specific nature of the EU as "a unique organization which possesses significant attributes of sovereignty not held by any other international organizations." 35

The 'Union Delegations' have been empowered with executive functions in all EU policy areas, ranging from agriculture and fisheries to development and humanitarian aid as well as trade issues. In many of the dossiers, Delegation staff often act as representatives of the Union on

with CFSP (see Case C-130/10, EP v Council (Restrictive measures directed against certain persons and entities associated with Usama bin Laden, the Al-Qaeda network and the Taliban), 19 July 2012).

33 See on the EEAS for instance B. Van Vooren, 'A Legal-Institutional Perspective on the European External Action Service' (2001) Common Market Law Review pp. 475-502; S. Blockmans and M.-J. Laatsit, 'The European External Action Service: Enhancing Coherence in EU External Action?' in Cardwell supra note 31, pp. $135-160$.

34 See in particular Benlolo-Carabot, supra note 4 at p. 785 when referring to the mission agreements through which the Delegations were established: "L'accord, rédigé à chaque fois en des termes similaires, permet à la delegation et à son personnel de jouir d'un status très protecteur par renvoi à la convention de Vienne sur les relations diplomatique de 1961."

35 Ibid. at 805-806, with a reference to the documents of the US Senate, $92^{\text {nd }}$ Session, Diplomatic Privileges and Immunities of the Mission of the European Communities, March 14, 1972, Report no. 92-687, pp. 19 and $24-25$. 
the basis of a certain mandate and in the execution of its tasks; the Delegation may quite easily be confronted with claims by individuals, enterprises or even from the host state itself. Although they are not in the public domain, the current mission agreements continue to reveal the extensive scope of the Delegation's privileges and immunities. It has been noted that it is striking that no reference is made to the immunities of the EU itself." ${ }^{36}$ The 2011 'Agreement between the European Union, the European Atomic Energy Community and the Government of the Republic of South Sudan on the Establishment and the Privileges and Immunities of the Delegation of the European Union in the Republic of South Sudan', for instance, reveals that the regulation of 'privileges and immunities' forms an integral element of the agreement on the 'establishment' of an EU Delegation. ${ }^{37}$ Article 3 of that agreement shows that the Vienna Convention on Diplomatic Relations is used as a basis and that the EU in a way 'contracts in' by accepting the application of the Convention, which leads to immunity of the EU Delegation and inviolability of its premises. At the same time, this agreement reflects the classic notion of reciprocity in international diplomatic law:

"1. The Delegation of the European Union, its Head and its members, as well as the members of their family forming part of their respective households, shall, on the territory of the Republic of South Sudan, enjoy such rights, privileges and immunities and be subject to such obligations as correspond to those laid down in the Vienna Convention on Diplomatic Relations of 18 April 1961 and respectively accorded to and assumed by Diplomatic Missions accredited to the Republic of South Sudan, the heads and members of those Missions, as well as the members of their families forming part of their respective households.

2. The other provisions of the Vienna Convention on Diplomatic Relations of 18 April 1961 shall be applicable mutatis mutandis.

3. Those rights and privileges and immunities shall be accorded on the condition that, in conformity with the provisions of article 16 of Protocol 7 on the privileges and immunities of the European Union ... the Member States of the European Union accord the same rights and privileges to the Mission of the Republic of South Sudan, to its Head and to its members, as well as to the members of their families forming part of their respective households."

Note that the concept of 'reciprocity' in this case seems to be stretched so as to include not the privileges and immunities of the mission of South Sudan at the EU, but rather at the EU Member States (who are formally not parties to this agreement). Identical or similar provisions can be found in agreements with other states. ${ }^{38}$

36 See Barbier \& Cuq, supra note 4, at p. 422, pointing to "l'absence dans les accords d'établissement de disposition expresse sur l'immunité de jurisdiction au benefice de l'organisation". The authors refer to this as a "bizarrerie" if compared to for instance the status of forces/mission agreements. The current establishment agreements do, however, address immunities quite extensively.

37 The mentioned agreements are on file with the author.

38 I have compared the agreements with Albania (1993), Azerbaijan (2008), Burundi (1988), Norway (1987), NewZealand (2004) and the United States (1972). 
The agreements with international organizations are often of a more complex nature because of the division of competences between the EU and its Member States, which are usually also members of the organization. However, they are usually drafted along the same lines. As privileges and immunities of foreign staff need to be granted by the host state (which, after all, will be the one exercising its domestic jurisdiction), it is usually necessary for host states to grant immunity to missions accredited to international organizations in their country. Thus, the privileges and immunities of the mission of the EU to the United Nations in New York are based on a Presidential Order, in which the President of the United States extends the privileges and immunities of the EU mission to the US to the EU mission at the United Nations. ${ }^{39}$

Apart from the EU Delegations, immunity is also explicitly provided for in cases where, on the basis of the EU's CSDP, an EU military or civilian mission deployed in a third country is covered by a SOFA (for military missions) or SOMA (for civilian missions). Over 20 of these agreements have been concluded with states in Africa, Asia and Eastern Europe. ${ }^{40}$ While it is not unusual in international law to confer diplomatic privileges and immunities on foreign military and civilian personnel, it has been noted that in the case of EU missions the privileges and immunities are much more extensive and are not only conferred on the higher ranking staff. ${ }^{41}$ The EU Model SOFA and $\mathrm{SOMA}^{42}$ grant EU missions personnel immunity from the criminal jurisdiction of the host state "under all circumstances" ${ }^{43}$ At the same time, the Sending State retains "all the criminal jurisdiction and disciplinary powers conferred on them by the law of the Sending State". ${ }^{44}$ Furthermore, the mission's personnel are exempted from the civil and administrative jurisdiction of the host state "in respect of words spoken or written and all acts performed by them in the exercise of their official functions". ${ }^{45}$ The extensive privileges and immunities for members of EU crisis management operations include the following: ${ }^{46}$ they are

39 See Executive Order 12851 of September 9, 1988, Federal Register, Vol. 55, No. 177, September 13, 1988, Presidential Documents.

40 See on these agreements Koutrakos, supra note 20, at 198-202; F. Naert, International law Aspects of the EU'S Security and Defence Policy, with a Particular Focus on the Law of Armed Conflict and Human Rights (Intersentia, Antwerp, 2010); A. Sari, 'Status of Forces and Status of Mission Agreements under the ESDP: The EU's Evolving Practice' (2008) European Journal of International Law p. 67.

41 Sari, supra note 40, at 78-79; also Naert, supra note 40, at 250, calling the situation "unusual".

42 See Draft Model Agreement on the status of the European Union-led forces between the European Union and a Host State, Council of the European Union (SOFA), 20 July 2007, Doc. 11894/07; and Draft Model Agreement on the Status of the European Union Civilian Crisis Management Mission in a Host State (SOMA), Council of the European Union, 15 December 2008, Doc. 17141/08.

43 Art. 6(3), EU Model SOFA; Art. 6(3), EU Model SOMA.

44 Art. 8, EU Model SOFA; Art. 8, EU Model SOMA.

45 Art. 6(4), EU Model SOFA; Art. 6(4), EU Model SOMA.

46 See more extensively Sari, supra note 40, at 91-92. 
not liable to any form of arrest or detention, nor are they obliged to give evidence as witnesses; no measures of execution can be taken against them, except in civil proceedings not related to their official functions; they are exempt from local social security provisions in respect of services rendered for the operation or mission; they are also exempt from any form of taxation in the host state on the salary and emoluments they receive from the missions and their sending state as well as on any income they receive from outside the host state; their papers, correspondence, and property enjoy inviolability, and their personal baggage is exempt from inspection; articles for their personal use are exempt from all customs duties, taxes, and related charges; mission personnel has the right to purchase free of duty or quantitative restrictions items required for their personal use and personnel is exempted from VAT and taxes for goods and services purchased on the domestic market.

As rightfully stated by Sari:

\begin{abstract}
"The attribution of privileges and immunities to CSDP personnel in order to enable them to carry out their mandate, as agreed between the EU and the host state, clearly constitutes a legitimate aim, especially where the terms of a status agreement simply give effect to the host state's obligations under customary international law to exempt foreign personnel from its jurisdiction on the basis of the principle of state immunity. By contrast, it is difficult, if not impossible, to decide on the basis of normative considerations whether the restrictions imposed by CSDP status agreements on the right to access courts is proportionate to the aim they pursue, that is whether the extent of the legal exemptions conferred on CSDP missions is proportionate to the objective of enabling them to carry out their mandate. ${ }^{47}$
\end{abstract}

However, as has been convincingly argued by Koutrakos, the extensive scope of the immunities may be explained on the basis of a number of factors: ${ }^{48}$

1) Ideas about CSDP varied widely among Member States and the EU was careful to organize its actions pursuant to legal and practical compromises and sought as enhanced a protection as possible for its personnel.

2) Given the many legal, political, and practical challenges internally, the natural reflex of the EU institutions is to minimize the legal problems which may arise externally.

3) The Union intervenes in states where the legal structures are either embryonic or in such decay that scepticism about submitting EU personnel to local jurisdictions is understandable.

4) At the beginning, the negotiators from the third states had no considerable experience in negotiating such agreements and were reluctant to challenge the Union's demands.

\footnotetext{
47 Sari, supra note 40, at p. 82. In this quote the former acronym 'ESDP' (European Security and Defence Policy) was replace by the current one: 'CSDP' (Common Security and Defence Policy).

48

Koutrakos, supra note 20, at p. 200.
} 


\section{EU Immunities in Practice}

\section{A. $\quad$ EU Immunities in EU Member States}

First of all, the EU may need to invoke its immunities in cases taking place before any of the courts in its own Member States. A case in point is the one in which the Dutch appeals court had ordered the public prosecutor to charge Euratom with infringing Dutch environmental regulations at its establishment in the Netherlands. ${ }^{49}$ As we have seen above, the Euratom Treaty contains an explicit immunity clause (Article 191) and the mentioned Protocol on Privileges and Immunities also applies to this organization. Nevertheless, in the appeals case, the Dutch court rejected the claim for immunity, arguing that the frequent and significant violations of the regulations committed by Euratom could not possibly be considered as being part of the supposed mission of the organization, and that criminal liability would not hinder the fulfilment of its mission. The court thus simply ignored the immunity clause by arguing that a claim for immunity could not hold in cases where an international organization violates this type of rule. Euratom participated in private law transactions on the same footing with other establishments that are not associated with an international organization; and, accordingly, all those establishments ought to comply with the law. Obviously, this type of reasoning turns the immunity clauses of international organizations into a dead letter and formed a reason for the Dutch Supreme Court to adopt a different view. More in line with established doctrine, the Supreme Court argued that immunity relates to the fulfilment of the organization's mission and that violations of environmental regulations fall in that category, leading to immunity from jurisdiction. In fact, the Court held on to the classic doctrine of the functional immunity of international organizations. While one may argue that the violation of domestic environmental regulations is not part of Euratom's objectives ${ }^{50}$ the Supreme Court nevertheless chose to save the procedural immunity of the organization. Any other outcome would allow national authorities to infringe on the organization's autonomy by setting substantive rules for its functioning.

A recent situation occured when the European Commission decided to inititate an infringment procedure before the European Court of Justice against Belgium (as its host state) for not complying fully with the provisions in the Union's Protocol on Privileges and

49 LJN: BA9173, Hoge Raad (Supreme Court of the Netherlands), 01984/07 CW, 13 November 2007. See C. Ryngaert, 'The Immunity of International Organizations before Domestic Courts' (2010) International Organziations Law Review pp. 121-148, at pp. 130-131.

$50 C f$. E. Gaillard \& I. Pingel-Lenuzza, 'International Organizations and Immunity from Jurisdiction: to Restrict or to Bypass' (2002) 51 International and Comparative Law Quarterly p. 1, at p. 10:

"Although this approach appears to be better suited for international organizations, it might result in immunity being granted to international organizations in all circumstances, given that international organizations will always be deemed to act within the scope of their duties." 
Immunities. ${ }^{51}$ The Commission has argued that, under the provisions governing the tax exemptions set out in the Protocol, the institutions cannot be required to pay taxes related to electricity and gas consumption. According to the Commission: ${ }^{52}$

\begin{abstract}
"[t]he purpose of the exemption is to prevent a Member State hosting an institution on its territory from benefiting from this and obtaining a tax advantage by imposing taxes that are financed by all the Member States' contributions to the EU budget, which is not justifiable in the eyes of European taxpayers."
\end{abstract}

Apart from the case before the EU Court, in 2011 the Commission also initiated proceedings before Belgian domestic Courts. All cases are still pending.

\title{
B. EU Immunities and Non-Member States
}

Having regard to lawsuits in third countries, practice offers a variety of different situations. These range from: traffic incidents involving EU Delegation staff, where in each case the EU examines whether to lift immunity or not for the purpose of local proceedings; to criminal proceedings against an international contracted staff member of an EU mission, where the local authorities put the person in question in prison, in clear violation of the relevant provisions of the Status of Mission Agreement (but where the host country reminded the EU that the SOMA also calls for mission staff to respect local laws and where the staff member could only be released after some diplomatic effort); and situations which prompt the question of whether an employment contract with local personnel was concluded by the Head of Delegation in his private or official capacity. ${ }^{53}$

Indeed, lawsuits are brought before foreign local jurisdictions against the organization itself or against EU staff. Similarly, the Commission noted that the addressees of judicial documents can vary: some are directed against the European Union as an organization and/or against the European Commission as an institution, and/or against the EU Delegation in a third country, or even against named Commission staff working in such delegations. It further noted that

"[i]n many instances the lawsuits relate to claims of private parties concerning the execution of programmes of financial and technical assistance, which the EU provides to non-EU countries. In such cases the EU can often rely on express provisions regarding jurisdictional immunity laid down in agreements with the host state regarding the establishment of the EU Delegation and in the relevant framework agreement concluded by the EU with the beneficiary non-EU state regarding the provision of financial and technical assistance." 54

51 See supra note 25.

52 See EU Commission, 'Commission goes to Court to make Belgium apply tax exemptions granted to Union institutions', 17 October 2013, Media Release, (Doc. IP/13/952), a copy of which is available at: $<$ http://europa.eu/rapid/press-release_IP-13-952_en.htm>.

53 Informal note of the European Commission on EU immunities, supra note 28.

54 Ibid. 
An example (with a similar outcome as the Euratom case discussed above) is provided by a ruling of an Israeli Court and is related to the 'commercial activities' of the European Commission. ${ }^{55}$ The case concerned a civil action against the European Commission. The Jerusalem Magistrate's Court determined that under Israeli law the European Commission is immune from suit because it is "an international organization" [sic] recognized by Israel under a 1992 Decree by the Israeli Foreign Minister. In relation to the commercial nature of the issue, the Court argued that

\begin{abstract}
"[i]In this matter, publishing a public tender seeking bids to perform work does indeed contain elements of a contract, which is private law. However, we should remember that the petitioner [the European Commission] is not a sovereign state but an international organization with certain goals. Publishing the tender and the performance of the works constitute expression and materialization of these goals. Therefore, the acts of the petitioner must be regarded as being within the public-governmental authority of the petitioner, and therefore it is entitled to immunity."
\end{abstract}

It has been argued that "if the European Commission were a sovereign state, it is likely that the lawsuit would proceed to a hearing on its merit, because sovereign immunity in Israel excludes commercial transactions." ${ }^{, 56}$ However, on the basis of customary international law "recognized organizations' were said to enjoy an almost absolute immunity, covering also commercial activities. $^{57}$

The general starting point is that the EU invokes immunity in cases in which the organization itself is being sued. This means that unless the Union has expressly waived its immunity, it should be exempted from the local jurisdiction of municipal, judicial or administrative authorities and therefore should not be subject to suits, claims or enforcement proceedings in these domestic forums. Despite its frequent claim that it should not be equated with other international organizations, it is interesting to note that in these cases the European Union often uses the argument that as an 'international organization' its claim of jurisdictional immunity is based on the rule of general (customary) international law which recognises that like States, international organizations are exempted from the local jurisdiction of municipal judicial or administrative authorities and therefore are not subject to suits, claims or enforcement proceedings in domestic forums. The immunity invoked is based on the principle of functionality: that is, an immunity that encompasses all acts needed for the execution of the official functions and activities of the organization. Therefore, the foregoing applies, in the view of the European

55 See H. Carmon, 'A Jerusalem Court Ruling: The European Commission is Immune to a Commercial Lawsuit', DIPLAW: Diplomatic / Consular Law and Sovereign Immunity in Israel and World Wide, 2009, available at http://diplomaticlaw.com/blog/2009/03/a-jerusalem-court-ruling-the-european-commission-is-immune-to-acommercial-lawsuit/. The author acted as a representative of the European Commission in this matter.

56 Ibid.

57 Ibid. 
Commission, even in the absence of express provisions laid down in international treaties and even when not expressly provided for in municipal law.

It is interesting to note that the Commission so easily relies on customary international law as a basis for the immunities of the EU. Apart from the fact that in many other occasions the Union continues to stress its sui generis nature in comparison to other international organizations, there is simply no extensive practice to easily base the claim on. ${ }^{58}$ Practice reveals that in local court cases, the EU frequently refers to the 1961 Vienna Convention on Diplomatic Relations in arguments to support the immunity of its diplomats and staff members, despite the fact that the EU itself is not a party to the Convention. ${ }^{59}$

The European Commission has noted that

\begin{abstract}
"[i]n cases where such jurisdictional immunity will need to be invoked in foreign local courts or administrative tribunals, the European Commission will via the EU Delegation respond by way of Note Verbale, informing the Ministry of Foreign Affairs of the non-EU country concerned that it invokes immunity from jurisdiction. In such a Note Verbale the delegation will also usually ask the Department of Foreign Affairs to take the appropriate steps to confirm with local courts that immunity is invoked. Where considered necessary or useful local counsel will be appointed to follow the proceedings and/or for to invoke jurisdictional immunity on behalf of the EU and/or its staff." ${ }^{, 60}$
\end{abstract}

Obviously, in these situations contacts between the legal advisor at a Union Delegation and the legal service at the EEAS in Brussels remain close, including so as to guarantee uniformity in the EU's policy in this regard and to prevent things from escalating.

No case is known in which non-EU courts have pronounced expressly on questions relating to the jurisdictional immunity of the EU. Put differently, there is no indication that there is a single instance in which a non-EU court has denied the jurisdictional immunity of European Union (or its predecessor, the European Community) from legal process. One reason may be that — as noted above — the European Union's legal system provides alternative remedies to which parties that have claims against it can have recourse. As we have seen, applicants may seek the annulment of an EU measure or they may invoke the non-contractual liability of the Union and bring a claim for damages. These remedies are available irrespective of the nationality of the party concerned and irrespective of where the challenged Union activity took place. Cases usually deal with a plea for annulment of a particular decision or a claim for damages, and because the EU system allows for this possibility the question of immunities simply does not arise. Plaintiffs can be foreign companies (for instance in anti-dumping or cartel situations) or third states. Thus, for instance, the American companies IBM and Microsoft are allowed to bring

58 See also Benlolo-Carabot, supra note 4, at p. 802: “La pratique n'est évidemment pas suffisante pour conclure à une immunité de [...] l'Union sur une base coutumière." See further the contribution by Michael Wood to this Forum.

59 Based on discussions with EU staff members and legal documents seen by the author.

60 Informal note of the European Commission on EU immunities, supra note 28. 
proceedings against the European Commission in a case concerning competition law, ${ }^{61}$ and Switzerland can do the same to challenge measures relating to the approaches to Zurich airport. ${ }^{62}$ In addition, in some situations cases are not brought to the Court using the 'direct actions' procedures, but reach Luxembourg through preliminary procedures as part of domestic proceedings in one of the EU Member States. Thus, in 2009, the American Air Transport Association and others brought judicial review proceedings before a British court asking the referring court to quash the measures implementing the directive in the United Kingdom. ${ }^{63}$ In fact, it happens quite often that foreign companies are confronted with EU legislation in the context of trade relations with one of the EU member states leading to a challenge of domestic rules that may be have an EU origin.

However, not all situations are covered. In contractual situations, not all contracts with third parties are by definition covered by EU law and the jurisdiction of the Court of Justice may need to be spelled-out explicitly. When this is not the case and a court in a third states declares itself incompetent because of the EU's immunity, plaintiffs may be left empty-handed. ${ }^{64}$ At the same time, the jurisdiction of the Court of Justice does not, in principle, extend to its actions under the common foreign, security and defence policy (see Articles 24(1) of the TEU and 275 of the TFEU), which also points to a possible legal protection deficit.

\section{EU Immunities and Staff Members}

As we have seen, the Protocol on Privileges and Immunities devotes abundant attention to the immunities of officials and staff members. Article 11 provides that

"In the territory of each Member State and whatever their nationality, officials and other servants of the Union shall:

(a) subject to the provisions of the Treaties relating, on the one hand, to the rules on the liability of officials and other servants towards the Union and, on the other hand, to the jurisdiction of the Court of Justice of the European Union in disputes between the Union and its officials and other servants, be immune from legal proceedings in respect of acts performed by them in their official capacity, including their words spoken or written."

Specific provisions relate to the position of Members of European Parliament. Thus, Article 8 provides that "Members of the European Parliament shall not be subject to any form of inquiry, detention or legal proceedings in respect of opinions expressed or votes cast by them in the

61 Case 60/81 International Business Machines Corporation v. Commission [1981] ECR 2639; Case T-167/08, Microsoft v. European Commission, 27 July 2012.

62 Case C-547/10 P Switzerland v. Commission, 7 March 2013.

63 Case C-366/10 Air Transport Association of America and Others, 3 February 2013.

64 Barbier \& Cuq, supra note 4, at p. 425. 
performance of their duties"; and Article 9 lists a number of specific rules "during the sessions of the European Parliament".

In a case concerning an MEP, the Court of Justice had a chance to interpret the provisions in the Protocol in this regard. ${ }^{65}$ The applicant, Mr Bruno Gollnisch, was a Member of the European Parliament, but also a Regional Councillor of the Rhône-Alps region, France. On 11 October 2004, he held a press conference at his political base in Lyon, discussing a number of politically sensitive issues. The press release formed a reason for the French Minister for Justice to order the opening of a police investigation, in particular regarding certain statements, which were regarded as calling into question the crimes against humanity committed by the National Socialist regime. Mr. Gollnisch filed a request for defence of his immunity. However, the European Parliament after examining the request, decided to waive his immunity and not to defend it. As a result, Mr. Gollnisch brought an action before the General Court seeking annulment of the decision of the Parliament and compensation for the non-material damage which he claims to have suffered. In relation to the immunities of the EU (or the European Communities at the time) as well as of MEPs, the Court of Justice held that: ${ }^{66}$

"while the privileges and immunities conferred on the European Communities by the Protocol have a functional character, inasmuch as they are intended to avoid any interference with the functioning and independence of the Communities, ${ }^{67}$ the fact remains that they have been expressly accorded to Members of the Parliament and to officials and other staff of the Community institutions. The fact that the privileges and immunities have been provided in the public interest of the Community justifies the power given to the institutions to waive the immunity where appropriate but does not mean that these privileges and immunities are granted to the Community exclusively and not also to its officials, to other staff and to Members of the Parliament. Therefore the Protocol confers an individual right on the persons concerned, compliance with which is ensured by the system of rights of recourse established by the Treaty." 68

The General Court rejected both actions brought by Mr. Gollnisch saying that the press release is irrelevant to his parliamentary duties since it was published by the Front National group of the Rhône-Alpes, of which he was president. The case underlines the classic functional approach in relation to the immunities of international organizations and the Court points to a clear distinction between the acts of MEPs as MEPs and other acts.

${ }^{65}$ Case T-42/06, Bruno Gollnisch v. European Parliament, Judgment of the General Court (Third Chamber) of 19 March 2010.

66 Ibid., at para 94.

67 Orders in Case 1/88 SA Générale de Banque v. Commission [1989] ECR 857, paragraph 9, and Case C-2/88 Imm. Zwartfeld and Others [1990] ECR I 3365, paragraph 19.

68 See to that effect, Case T 345/05 Mote v. Parliament [2008] ECR II 2849, paragraph 28; see also, by analogy, Case 6/60 Humblet v. État Belge [1960] ECR 559, 571. 


\section{Conclusion}

The question of privileges and immunities is a classic theme in the law of international organizations. Yet, the immunities of the European Union have never been given much attention in academic literature. One reason may be that, because of the extensive (and often exclusive) jurisdiction of the Court of Justice of the EU, issues can or must often be solved at that level. Whereas most international organizations lack a judicial forum for individuals to bring claims, the EU's well-developed legal order allows any natural or legal person, whatever his nationality or residence, to institute proceedings against a decision addressed to him or which is of direct and individual concern. However, the EU is also a special international organization with extensive relations with non-EU states. The new global ambitions of the EU, inter alia reflected in the establishment of the European External Action Service, the connected 'Union Delegations' in a global network of 'EU embassies', as well as the coming of age of the Union's security and defence policy, all raise new possibilities for conflict, both under international law and under the domestic law of non-EU states.

The privileges and immunities of the EU, its institutions and its staff have been regulated quite extensively in its primary law (the treaties and a special protocol) as well as in international agreements concluded between the EU and third states or other international organizations. These agreements may concern the establishment of a Union Delegation or the status of forces and missions in the framework of the Union's security and defence policy. Often the recognised special nature of the EU or the inexperience of some third states in the early days of the Union's military missions resulted in a comfortable immunity regime for the EU. Yet, it is important to realise that, despite of the fact that the EU is not a state, the general rules of international diplomatic law in this respect usually form the basis for the legal regime underlying the presence of the EU abroad. Indeed, in many cases references are more easily made to the diplomatic immunities of states than to those of international organizations.

The complex division of competences between the EU and its Member States clearly differs from any other international organization and may result in additional confusion. While practice reveals that the EU as such (as well as its Institutions or staff members) may become party to lawsuits, so far no cases are known in which (in the end) the immunity of the EU was not accepted. However, the role of the EU Court of Justice will be increasingly important in balancing the different ambitions of the EU: its role as a global actor and active participant in international trade; development and security issues with serious consequences for individuals; and the international example the EU wishes to set in terms of what it calls "respect for human dignity, freedom, democracy, equality, the rule of law and respect for human rights". 69

69 Article 2 of the TEU (see also Article 6). 